\title{
PENGARUH PENGALAMAN DAN DORONGAN KELUARGA TERHADAP MOTIVASI BERWIRAUSAHA MAHASISWA PENDIDIKAN EKONOMI UNIVERSITAS PGRI RONGGOLAWE TUBAN
}

\author{
Mario Fahmi Syahrial \\ Program Studi Pendidkan Ekonomi, Fakultas Keguruan dan Ilmu Pendidikan \\ Universitas PGRI Ronggolawe Tuban \\ mariofahmi@unirow.ac.id
}

Diterima: November 2018. Disetujui: Desember 2018. Dipublikasikan: Januari 2019

\begin{abstract}
The ability to become an entrepreneur requires experience and flying hours. Entrepreneurial skills in higher education can be honed by participating in Job Training or Job Practices. The experience of education and learning obtained from various environments, both in the school, family, community and nature environment is able to provide experience about entrepreneurship. Experience was gained from an environment that became an entrepreneurial center. This is the same as families or parents who become entrepreneurs or not become entrepreneurs will provide experience to their children. The method used in this study was quantitative research and research locations at the University of PGRI Ronggolawe Tuban Economic education study program. The total population of 136 students of Economic education in the class of 2014 and 57 students became samples. This study uses a propotional random sampling technique.

The results showed that the experience of entrepreneurship and family motivation had an influence on motivation for students of economic education at the University of PGRI Ronggolawe Tuban, Experience of Entrepreneurship and Family Encouragement together had an effect on Entrepreneurial Motivation, There were other factors (variables) which were not included in this model influence on motivation for entrepreneurship.
\end{abstract}

Keywords: entrepreneurial experience, family drive, entrepreneurial motivation

\begin{abstract}
ABSTRAK
Kemampuan untuk menjadi wirausaha membutuhkan pengalaman dan jam terbang. Kemampuan wirausaha di perguruan tinggi dapat diasah dengan mengikuti Job Training atau Praktik Kerja. Pengalaman pendidikan dan pembelajaran yang diperoleh dari berbagai lingkungan, baik di lingkungan sekolah, keluarga, masyarakat dan alam mampu memberikan pengalaman tentang wirausaha. Pengalaman didapat dari lingkungan yang menjadi sentra wirausaha. Hal ini sama dengan keluarga atau orang tua yang menjadi wirausaha atau tidak menjadi wirausaha akan memberikan pengalaman kepada anaknya. Metode yang digunakan dalam penelitian ini adalah penelitian kuantitatif dan lokasi penelitian di Universitas PGRI Ronggolawe Tuban program studi pendidikan Ekonomi. Jumlah populasi 136 mahasiswa pendidikan Ekonomi angkatan 2014 dan 57 mahasiswa menjadi sempel. Penelitian ini menggunakan teknik propotional random sampling.

Hasil penelitian menunjukan bahwa Pengalaman berwirausaha dan dorongan keluarga memberikan pengaruh terhadap motivasi bagi mahasiswa pendidikan ekonomi Universitas PGRI Ronggolawe Tuban, Pengalaman Berwirausaha dan Dorongan Keluarga secara bersama-sama berpengaruh terhadap Motivasi Berwirausaha, Terdapat faktor (variabel) lain yang tidak masuk dalam model ini yang memberi pengaruh terhadap motivasi untuk berwirausaha.
\end{abstract}

Kata kunci: pengalaman berwirausaha,dorongan keluarga, motivasi berwirausaha 


\section{PENDAHULUAN}

Dunia entrepreneur (wirausaha) bagi negara maju sangatlah penting. Semakin maju suatu negara semakin banyak orang yang terdidik dan banyak juga orang yang mengganggur. Perguruan tinggi sebagai lembaga pendidikan haruslah sudah memulai mendorong budaya berwirausaha bagi mahasisiwa. Perguruan tinggi juga diharapkan mampu menciptakan wirausaha-wirausaha yang handal, sehingga mampu memberi stimulus khususnya bagi mahasiswa untuk berwirausaha. Mahasiswa sebagai komponen penting bagi masyarakat, diharapkan mampu, memberi harapan untuk dapat membuka lapangan pekerjaan, dengan menumbuhkan motivasi untuk menjadi wirausaha.

Perkembangan dunia kewirausahaan di Indonesia masih sangat kurang yaitu dibawah 2\%. Sebagai pembanding, kewirausahaan di Amerika Serikat tercatat mencapai $11 \%$ dari total penduduknya, Singapura sebanyak 7\%, dan Malaysia sebanyak 5\%. Perkembangan dunia kewirausahaan di Indonesia sangatlah lambat, hal ini dikarenakan oleh pandangan dan kepercayaan secara turun-menurun, bahwa ketika seseorang telah melanjutkan studi di perguruan tinggi maka harus menjadi pegawai negeri sipil atau aperatur sipil negara.

Pendidikan kewirausahaan yang diajarkan di sekolah-sekolah dan perguruan tinggi belumlah maksimal. Pendidikan kewirausahaan adalaha salah satu faktor utama untuk menumbuhkan dan mengembangkan hasrat, jiwa dan perilaku berwirausaha di kalangan generasi muda Sehubungan dengan pengaruh pendidikan kewirausahaan, maka diperlukan adanya pemahaman tentang bagaimana mendorong dan mengembangkan lahirnya wirausaha-wirausaha muda yang potensial, walaupun masih diusia sekolah.

Terlahirnya wirausaha muda potensial diharapkan mampu menjawab tantangan untuk menjadi pencipta dan pembuka lapangan kerja. Kemampuan untuk menjadi wirausaha membutuhkan pengalaman dan jam terbang. Kemampuan wirausaha di perguruan tinggi dapat diasah dengan mengikuti Job Training atau Praktik Kerja. Job training dan praktik kerja sangat bermanfaat bagi mahasiswa untuk meningkatakan kemampuan wirausaha dan juga untuk menentukan jenis usaha yang akan dilakukan. Pengalaman berwirausaha juga didapat dari pengalaman orang lain dalam bidang yang diinginkan. Pengalaman pribadi maupun pengalaman orang lain yang telah berhasil dan sukses dalam wirausaha, dapat dijadikan pedoman atau guru agar terhindar dari kegagalan dalam menjalankan usahanya. 
Guna mendorong terlahirnya wirausaha muda potensial, selain dorongan dari lingkungan akademis juga diperlukan dorongan berbentuk motivasi yang kuat untuk maju dari pihak keluarga merupakan modal awal untuk menjadi wirausaha (Kasmir, 2007:5).

Keluarga merupakan lingkungan pertama dan utama dalam proses sosialisasi dan internalisasi dalam proses pembentukan sikap,perilaku, karakter, dan mental. Proses interaksi didalam keluarga, seorang anak bukan hanya mengidentifikasi diri dengan orang tuanya dan anggota keluarga, melainkan juga mengidentifikasi kehidupan didalam masyarakat dan alam sekitar.

Pengalaman pendidikan dan pembelajaran yang diperoleh dari berbagai lingkungan, baik di lingkungan sekolah, keluarga, masyarakat dan alam mampu memberikan pengalaman tentang wirausaha. Pengalaman didapat dari lingkungan yang menjadi sentra wirausaha. Hal ini sama dengan keluarga atau orang tua yang menjadi wirausaha atau tidak menjadi wirausaha akan memberikan pengalaman kepada anaknya.

Motivasi untuk berwirausaha tidak cukup hanya dibekali dengan pengetahuan, pengalaman atau pendidikan kewirausahaan, melainkan dibutuhkan bekal ketrampilan mengenai bidang yang akan dijadikan usaha atau fokus bidang usaha. Dorongan pihak keluarga mereka dapat dijadikan dorongan dan motivasi sebagai faktor pendorong utama untuk menumbuhkan motivasi berwirausaha.

Dorongan keluarga atau orang tua sangatlah penting dalam menumbuhkan motivasi berwirausaha pada mahasiswa. Pendidikan kewirausahaan dapat dimulai seja dini dalam lingkungan keluarga. Memiliki seorang orang tua yang berwirausaha dapat memberikan contoh kepada anak untuk menjadi wirausahawan.

Adanya pengalaman berwirausaha dan dorongan keluarga, diharapkan akan berpengaruh positif terhadap motivasi berwirausaha mahasiswa secara keseluruhan, maka akan dilaksanakan penelitian dengan judul; pengaruh pengalaman dan dorongan keluarga terhadap motivasi berwirausaha mahasiswa pendidikan ekonomi Universitas PGRI Ronggolawe Tuban. 


\section{KAJIAN PUSTAKA}

\section{Kewirausahaan}

Kewirausahaan merupakan suatu kemampuan dalam hal menciptakan kegiatan usaha". Kemampuan menciptakan memerlukan adanya kreatifitas dan inovasi yang terus menerus untuk menemukan sesuatu yang berbeda dari yang sudah ada sebelumnya (Kasmir, 2011: 21). Menurut Suryana (2013:2), Kewirausahaan merupakan suatu disiplin ilmu yang memepelajari tentang nilai, kemampuan (ability), dan perilaku seseorang dalam menghadapi tantangan hidup dan cara memperoleh peluang dengan berbagai resiko yang mungkin dihadapinya.

\section{Pengalaman Berwirausaha}

Pengalaman merupakan guru yang terbaik. Kompetensi hanya dapat dicapai dalam jangka panjang (Kristanto, 2009: 18) mengatakan bahwa "pengalaman dalam menjalankan usaha yang telah didapatkan merupakan salah satu kunci keberhasilan dalam menjalankan bisnis, terutama jika bisnis baru yang akan dijalankan ini berhubungan dengan pengalaman bisnis yang sebelumnya”.

\section{Motivasi Berwirausaha}

Motivasi pada dasarnya adalah penerimaan suatu hubungan antara diri sendiri dengan sesuatu di luar pribadi sehingga kedudukan motivasi tidaklah stabil karena dalam kondisi-kondisi tertentu, motivasi dapat berubah-rubah, tergantung faktor-faktor yang mempengaruhinya.Motivasi bertalian erat dengan perhatian, maka faktor-faktor tersebut adalah pembawaan, suasana hati atau perasaan, keadaan lingkungan, perangsang dan kemauan (Nurwakhid,23: 1995).

(Venesaar et al :2006:104) menjelaskan bahwa motivasi seseorang menjadi wirausaha dibagi dalam tiga dimensi, yaitu Ambition for freedom (aktivitas lebih bebas, memiliki usaha sendiri, menjadi lebih dihormati, terdepan dalam menerapkan ide baru, mengembangkan hobi dalam bisnis), Self-realisation (Memperoleh posisi yang lebih baik di masyarakat, Merasakan tantangan, Memotivasi dan memimpin orang lain, Melanjutkan tradisi keluarga, Mengimplementasikan ide atau berinovasi, Mengikuti orang lain), Pushing factors (Kehilangan pekerjaan, Memperoleh pendapatan yang lebih baik, Tidak puas dengan pekerjaan). 


\section{Dorongan Keluarga}

Dorongan berbentuk motivasi yang kuat untuk maju dari pihak keluarga merupakan modal awal untuk menjadi wirausaha". Keluarga merupakan lingkungan pertama dan utama bagi anak yang memberikan sumbangan bagi perkembangan dan pertumbuhan mental maupun fisik dalam kehidupannya(Kasmir: 2011:5). Dorongan keluarga merupakan suatu bantuan yang diberikan anggota keluarga seperti orang tua, kakak maupun adik berupa pandangan, pendapat, nasehat, penghargaan, informasi dan material yang menyebabkan efek tindakan atau emosional yang menguntungkan bagi individu dalam membantu individu membuat keputusan

Lingkungan keluarga adalah salah satu faktor lingkungan yang dapat mempengaruhi motivasi seseorang untuk berwirausaha. Adapun faktor-faktor yang terkandung dalam keluarga menurut Slameto (22:2003) lingkungan keluarga terdiri dari Cara orang tua mendidik, Relasi antar anggota keluarga, Suasana rumah, Keadaan ekonomi keluarga, Pengertian Orang Tua, dan Latar Belakang Kebudayaan.

\section{METODE PENELITIAN}

\section{Jenis Penelitian}

Metode yang digunakan dalam penelitian ini adalah penelitian kuantitatif. Penelitian kuantitatif adalah penelitian yang menekankan pada pengujian teori-teori melalui pengukuran variabel-variabel penelitian dengan angka dan melakukan analisis data dengan prosedur statistik .Penelitian ini menggunakan pedoman wawancara dan data angket.

\section{Tempat dan Waktu Penelitian}

Penelitian ini dimulai pada bulan Maret sampai bulan Agustus 2018 di Universitas PGRI Ronggolawe Tuban program studi pendidikan Ekonomi .

\section{Populasi dan Sempel}

Populasi dalam penelitian ini merupakan mahasiswa pendidikan ekonomi angkatan 2014 yaitu sebanyak 136 orang. Penentuan jumlah sampel menurut Slovin ( Sujarweni, 2014: 14), dari jumlah populasi 136 mahasiswa adalah 57 mahasiswa menjadi sempel. Penelitian ini menggunakan teknik propotional random sampling. 


\section{HASIL PENELITIAN}

\section{Pengujian Hipotesis}

\section{Pengaruh Pengalaman terhadap motivasi berwirausaha}

Uji t digunakan untuk mengetahui apakah Pengalaman Berwirausaha (X1) berpengaruh secara signifikan atau tidak terhadap Minat Berwirausaha (Y), pengujian menggunakan tingkat signifikasi 0,05 dan 2 sisi.

\section{Tabel 1}

Uji -t variabel X1 terhadap Y

\begin{tabular}{|c|c|c|c|}
\hline \multicolumn{4}{|c|}{ Coefficients $^{\mathrm{a}}$} \\
\hline \multicolumn{2}{|c|}{ Model } & $\mathrm{T}$ & Sig. \\
\hline \multirow[t]{2}{*}{1} & (Constant) & 7,597 &, 000 \\
\hline & Pengalaman Berwirausaha & 14,571 &, 000 \\
\hline
\end{tabular}

a. Dependent variable motivasi berwirausaha.

Sumber: Data diolah SPSS v.22

Dari tabel tersebut dapat dilihat bahwa nilai t hitung $>\mathrm{t}$ tabel $(14,571>2,004)$ dan signifikansi $<0,05(0,000<0,05)$, maka Ho ditolak. Jadi, dapat disimpulkan bahwa Pengalaman Berwirausaha berpengaruh terhadap Minat Berwirausaha.

\section{Pengaruh dorongan keluarga terhadap motivasi berwirausaha}

Uji t digunakan untuk mengetahui apakah Dukungan Keluarga (X2) berpengaruh secara signifikan atau tidak terhadap Minat Berwirausaha(Y), pengujian menggunakan tingkat signifikasi 0,05 dan 2 sisi.

\section{Tabel 2}

\section{Uji -t variabel X2 terhadap Y}

\begin{tabular}{|l|l|c|c|}
\hline \multicolumn{4}{|c|}{ Coefficients $^{\mathbf{a}}$} \\
\hline \multicolumn{2}{|l|}{} & $\mathrm{T}$ & Sig. \\
\hline \multirow{2}{*}{ Model } & (Constant) & 7,597 &, 000 \\
& Pengalaman Berwirausaha & 14,571 &, 000 \\
\hline & & $\cdots$
\end{tabular}

a. Dependent Variabe: Motivasi Berwirausaha

Sumber: data diolah SPSS v.22

Dari tabel diatas dapat diketahui bahwa nilai t hitung $>\mathrm{t}$ tabel $(9,710>2,004)$ dan signifikansi $<0,05(0,000<0,05)$, maka Ho ditolak. Jadi, dapat disimpulkan bahwa dorongan Keluarga berpengaruh terhadap Minat Berwirausaha. 


\section{Pengaruh Pengalaman Berwirausaha dan Dorongan Keluarga terhadap motivasi Berwirausaha.}

Uji t digunakan untuk mengetahui secara parsial Pengalaman Berwirausaha dan Dukungan Keluarga berpengaruh secara signifikan atau tidak terhadap Minat Berwirausaha. Pengujian menggunakan tingkat signifikasi 0,05 dan 2 sisi. Berikut kami sajikan tabel 2hasil analisi uji t variabel X1 (Pengalaman Berwirausaha) dan X2 (Dorongan Keluarga) terhadap variabel Y (Motivasi Berwirausaha).

Tabel 3

\section{Uji -t variabel X1 dan X2 terhadap Y}

\begin{tabular}{|l|l|r|r|}
\hline \multicolumn{5}{|c|}{ Coefficients $^{\mathbf{a}}$} \\
\hline \multirow{2}{*}{ Model } & & \multicolumn{1}{c|}{$\mathrm{T}$} & \multicolumn{1}{c|}{ Sig. } \\
\hline 1 & (Constant) & 7,597 &, 000 \\
& Pengalaman Berwirausaha & 14,571 &, 000 \\
\hline
\end{tabular}

a. Dependent Variable: Motivasi Berwirausaha

Sumber : Data diolah SPSS v.22

Dari tabel diatas dapat disimpulkan $t$ hitung $>\mathrm{t}$ tabel $(7,335>2,005)$ dan signifikansi $<0,05(0,000<0,05)$, maka Ho ditolak. Jadi, dapat disimpulkan bahwa Pengalaman Berwirausaha berpengaruh terhadap Motivasi Berwirausaha dan nilai $t$ hitung $>-t$ tabel $(2,490>1,996)$ dan signifikansi $<0,05(0,016<0,05)$, maka Ho ditolak. Jadi, dapat disimpulkan bahwa Dorongan Keluarga berpengaruh terhadap Motivasi Berwirausaha.

\section{Signifikansi pengaruh Pengalaman Berwirausaha dan Dorongan Keluarga Terhadap Motivasi Berwirausaha Mahasiswa Pendidikan Ekonomi Universitas PGRI Ronggolawe Tuban}

Pengujian menggunakan tingkat signifikansi 0,05. Berikut tabel 4 hasil analisi uji $\mathrm{F}$ (anova) pengaruh variabel X1 (Pengalaman Berwirausaha) dan X2 (Dorongan Keluarga) terhadap variabel Y (Motivasi Berwirausaha). 


\section{Tabel 4.}

\section{Uji F Anova}

\begin{tabular}{|c|c|c|c|c|}
\hline \multicolumn{5}{|c|}{ ANOVAa $^{a}$} \\
\hline \multicolumn{2}{|c|}{ Model } & $\mathrm{Df}$ & $\mathrm{F}$ & Sig. \\
\hline \multirow[t]{3}{*}{1} & Regression & 2 & 119,296 & $.000^{\mathrm{b}}$ \\
\hline & Residual & 54 & & \\
\hline & Total & 56 & & \\
\hline \multicolumn{5}{|c|}{ a. Dependent Variable: Motivasi Berwirausaha } \\
\hline \multicolumn{5}{|c|}{$\begin{array}{l}\text { b. Predictors: (Constant), Dorongan Keluarga, } \\
\text { Pengalaman Berwirausaha }\end{array}$} \\
\hline
\end{tabular}

Dari tabel diatas bahwa $\mathrm{F}$ hitung $>\mathrm{F}$ table $(119,296>3,168)$ dan signifikansi < $0,05(0,000<0,05)$, maka Ho ditolak. Jadi dapat disimpulkan bahwa Pengalaman Berwirausaha dan Dorongan Keluarga secara bersama-sama berpengaruh terhadap Motivasi Berwirausaha.

\section{Uji regresi secara parsial}

a. Regresi Linier Parsial antara Variabel X1 terhadap Y

Analisis ini untuk mengetahui arah hubungan antara variabel.Berikut ini adalah hasil analisis pengujian hipotesisyaitu adanya pengaruh Pengalaman Berwirausaha(X1) terhadap Motivasi Berwirausaha(Y)

\section{Tabel 5.}

\section{Model Summary variabel X1 terhadap variabel Y}

\begin{tabular}{|l|c|r|r|r|}
\hline \multicolumn{5}{|c|}{ Model Summary } \\
\hline Model & R & R Square & $\begin{array}{c}\text { Adjusted R } \\
\text { Square }\end{array}$ & $\begin{array}{c}\text { Std. Error of } \\
\text { the Estimate }\end{array}$ \\
\hline 1 &, $891^{\mathrm{a}}$ &, 794 &, 791 & 2,206 \\
\hline
\end{tabular}

a. Predictors: (Constant), Pengalaman Berwirausaha

Sumber: Data diolah SPSS v. 22

Angka $\mathrm{R}$ didapat 0,793 , artinya korelasi antara variable "Pengalaman Berwirausaha" dengan "Motivasi Berwirausaha" sebesar 0,891. hal ini berarti terjadi hubungan yang erat/ kuat karena nilai $\mathrm{R}$ mendekati nilai 1 .

R Square (R2) atau kuadrat R nilainya sebesar 0,794, artinya persentase sumbangan pengaruh variable "Pengalaman Berwirausaha" terhadap "Motivasi Berwirausaha" sebesar 79,4\%, sedangkan sisanya sebesar $20,6 \%$ dipengaruhi oleh variable lain yang tidak dimasukkan dalam model ini. 


\section{Tabel 6.}

\section{Coefficients variabel $\mathrm{X} 1$ terhadap variabel $\mathrm{Y}$}

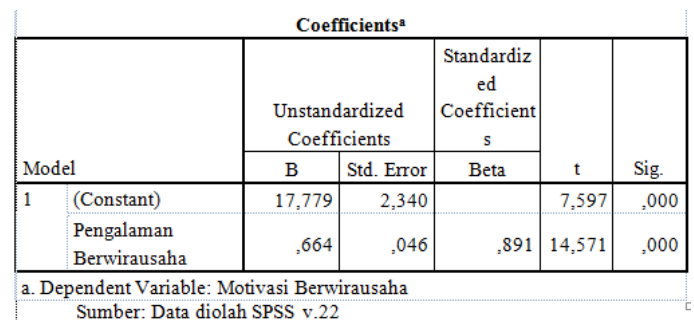

Nilai konstanta (a) adalah 17,779; artinya, jika Pengalaman Berwirausahabernilai 0 (nol), maka Motivasi Berwirausaha bernilai positif (naik), yaitu 17,779 dan Nilai koefisien regresi variabel Pengalaman Berwirausaha(b) bernilai positif, yaitu 0,664; ini dapat diartikan bahwa setiap kenaikan Pengalaman Berwirausahasebesar 1, maka Motivasi Berwirausaha juga meningkat sebesar 0,664.

\section{Tabel 7.}

\section{Koefisiensi Determinan}

\begin{tabular}{|l|c|r|r|r|}
\hline \multicolumn{7}{|c|}{ Model Summary } \\
\hline Model & R & R Square & $\begin{array}{c}\text { Adjusted R } \\
\text { Square }\end{array}$ & $\begin{array}{c}\text { Std. Error of } \\
\text { the Estimate }\end{array}$ \\
\hline 1 &, $891^{\mathrm{a}}$ &, 794 &, 791 & 2,206 \\
\hline
\end{tabular}

Dari tabel diaats dapat dihitung persentase sumbangan pengaruh variable Pengalaman Berwirausaha terhadap Motivasi Berwirausaha" sebesar 79,4\%, sedangkan sisanya sebesar $37,1 \%$ dipengaruhi oleh variable lain yang tidak dimasukkan dalam model ini.

\section{b. Regresi Linier Parsial antara Variabel X2 terhadap Y}

Analisis ini untuk mengetahui arah hubungan antara variabel.Berikut ini adalah hasil analisis pengujian hipotesisyaitu adanya pengaruh Dorongan Keluarga(X2) terhadap Motivasi Berwirausaha(Y) 
Tabel 8.

Model Summary variabel X2 terhadap variabel Y

\begin{tabular}{|l|c|r|r|r|}
\hline \multicolumn{5}{|c|}{ Model Summary } \\
\hline Model & R & R Square & $\begin{array}{c}\text { Adjusted R } \\
\text { Square }\end{array}$ & $\begin{array}{c}\text { Std. Error of } \\
\text { the Estimate }\end{array}$ \\
\hline 1 &, $795^{\mathrm{a}}$ &, 632 &, 625 & 2,953 \\
\hline
\end{tabular}

a. Predictors: (Constant), Dorongan Keluarga

Sumber: Data diolah SPSS v. 22

Angka R didapat 0,795, artinya korelasi antara variable "Dorongan Keluarga" dengan "Motivasi Berwirausaha" sebesar 0,795. hal ini berarti terjadi hubungan yangcukup erat/ cukup kuat karena nilai R mendekati nilai 1.

$\mathrm{R}$ nilainya sebesar 0,632, artinya persentase sumbangan pengaruh variable "Dorongan Keluarga" terhadap"Motivasi Berwirausaha" sebesar 63,2\%, sedangkan sisanya sebesar $36,8 \%$ dipengaruhi oleh variable lain yang tidak dimasukkan dalam model ini.

\section{Tabel 9.}

\section{Coefficients variabel $\mathrm{X} 2$ terhadap variabel $\mathrm{Y}$}

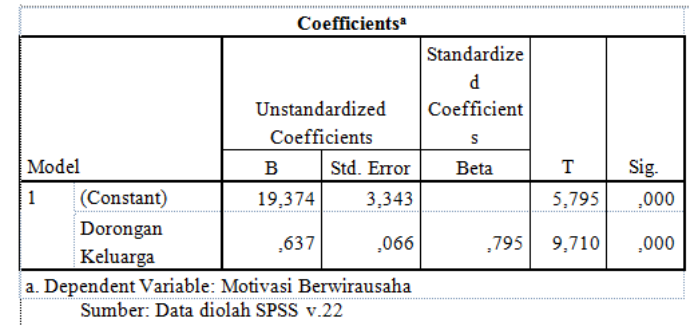

Nilai konstanta (a) adalah 19,374; artinya, jika Dorongan Keluargabernilai 0 (nol), maka Motivasi Berwirausahabernilai positif (naik), yaitu 19,374 dan Nilai koefisien regresi variabel Dorongan Keluarga (b) bernilai positif, yaitu 0,637; ini dapat diartikan bahwa setiap kenaikan Dorongan Keluarga sebesar 1, maka Motivasi Berwirausahajuga meningkat sebesar 0,637 .

\section{Tabel 10.}

\section{Koefisiensi Determinan}

\begin{tabular}{|c|c|c|c|c|}
\hline \multicolumn{5}{|c|}{ Model Summary } \\
\hline Model & $\mathrm{R}$ & R Square & $\begin{array}{l}\text { Adjusted R } \\
\text { Square }\end{array}$ & $\begin{array}{l}\text { Std. Error of } \\
\text { the Estimate }\end{array}$ \\
\hline 1 & $795^{\mathrm{a}}$ & .632 &, 625 & 2,953 \\
\hline
\end{tabular}


Dari hasil perhitungan persentase sumbangan pengaruh variable Dorongan Keluarga terhadap Motivasi Berwirausaha sebesar 63,2\%, sedangkan sisanya sebesar $36,8 \%$ dipengaruhi oleh variable lain yang tidak dimasukkan dalam model ini.

\section{Uji regresi secara simultan}

Analisis ini untuk mengetahui arah hubungan antara variabel. Berikut ini adalah hasil analisis pengujian hipotesis yaitu adanya pengaruh Pengalaman Berwirausaha(X1) dan Dorongan Keluarga(X2) terhadap Motivasi Berwirausaha(Y)

Tabel 11.

\section{Model Summary variabel X1 dan X2 terhadap variabel Y}

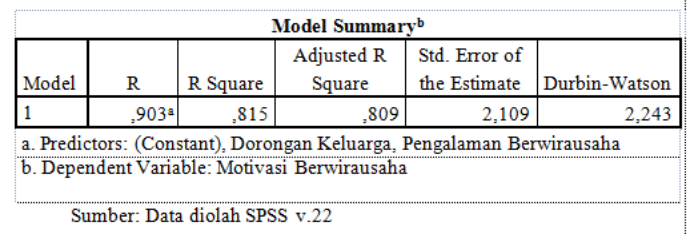

Dari tabel diatas diketahui variable $\mathrm{X}$ dan $\mathrm{Y}$. Angka $\mathrm{R}$ didapat 0,903, artinya korelasi antara variable Pengalaman Berwirausaha(X1) dan Dorongan Keluarga(X2) dengan Motivasi Berwirausaha(Y) sebesar 0,903. hal ini berarti terjadi hubungan yang erat/ kuat karena nilai R mendekati nilai 1 dan R Square (R2) atau kuadrat R nilainya sebesar 0,815, artinya persentase sumbangan pengaruh variable Pengalaman Berwirausaha(X1) dan Dorongan Keluarga(X2) terhadap Motivasi Berwirausaha(Y) sebesar $81,5 \% \%$, sedangkan sisanya sebesar $18,5 \%$ dipengaruhi oleh variable lain yang tidak dimasukkan dalam model ini.

Tabel 12.

\section{Coefficients variabel X1dan X2 terhadap variabel Y}

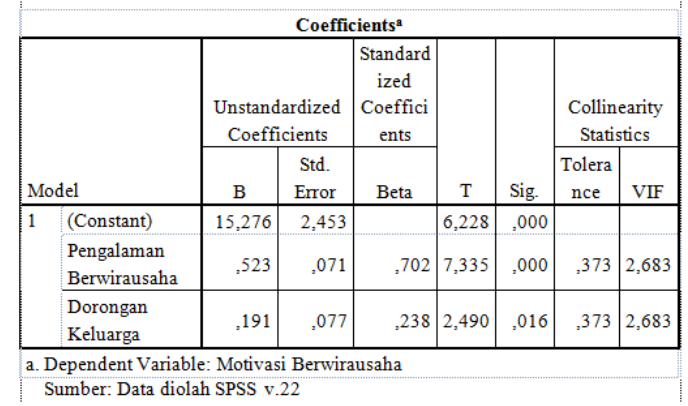


Dari tabel diatas dapat diketahui nilai konstanta (a) adalah 15,276; artinya, jika Pengalaman Berwirausaha dan Dorongan Keluarga bernilai 0 (nol), maka Motivasi Berwirausahabernilai positif (naik), yaitu 15,276.

Nilai koefisien regresi variabel Pengalaman Berwirausaha(b1) bernilai positif, yaitu 0,523; ini dapat diartikan bahwa setiap kenaikan Pengalaman Berwirausaha sebesar 1, maka Motivasi Berwirausahajuga meningkat sebesar 0,523.

Nilai koefisien regresi variabel Dorongan Keluarga (b2) bernilai positif, yaitu 0,191; ini dapat diartikan bahwa setiap kenaikan Dorongan Keluarga sebesar 1, maka Motivasi Berwirausahajuga meningkat sebesar 0,191.

\section{Tabel 13.}

\section{Koefisiensi Determinan}

\begin{tabular}{|c|c|c|c|c|c|}
\hline \multicolumn{6}{|c|}{ Model Summary ${ }^{b}$} \\
\hline Model & $\mathrm{R}$ & R Square & $\begin{array}{c}\text { Adjusted R } \\
\text { Square }\end{array}$ & $\begin{array}{l}\text { Std. Error of } \\
\text { the Estimate }\end{array}$ & $\begin{array}{l}\text { Durbin- } \\
\text { Watson }\end{array}$ \\
\hline 1 & $903^{\mathrm{s}}$ & 815 & 809 & 2,109 & 2,243 \\
\hline \multicolumn{6}{|c|}{ 1arga, Pengalaman Berwirausaha } \\
\hline b. Depe & ent Varia & ble: Motiva & Berwirausa & & \\
\hline
\end{tabular}

Tabel diatas dapat diketahui bahwakoefisien determinasi (r2) yang dinyatakan dalam persentase. hasil perhitungan dapat disimpulkan persentase sumbangan pengaruh variable "Pengalaman Berwirausaha(X1) dan Dorongan Keluarga(X2) terhadap variabel Y (Motivasi Berwirausaha)" sebesar 81,5\%, sedangkan sisanya sebesar 18,5\% dipengaruhi oleh variable lain yang tidak dimasukkan dalam model ini.

\section{PEMBAHASAN}

Pengalaman dan dorongan keluarga memberikan motivasi untuk berwirausaha bagi mahasiswa pendidikan ekonomi Universitas PGRI Ronggolawe Tuban. Hal ini dilihat dari hasil penelitian dimana dari hasil uji t diketahui bahwa pengalaman berwirausaha dan dorongan keluarga memberikan pengaruh yang signifikan terhadap motivasi berwirausaha. Pengalaman berwirausaha berdasarkan hasil wawancara diketahui bahwa mahasiswa termotivasi berwirausaha karena pengalaman pernah menjadi pelayan toko, kasir, dan marketing. Pengalaman dalam menjalankan usaha yang telah didapatkan merupakan salah satu kunci keberhasilan dalam menjalankan bisnis, terutama jika bisnis baru yang akan dijalankan ini berhubungan dengan pengalaman bisnis yang sebelumnya. Dorongan keluarga berdasarkan hasil wawancara diketahui bahwa mahasiswa termotivasi untuk berwirausaha karena ingin meneruskan usaha keluarga, 
adanya keinginan untuk mengembangkan diri. Hal ini dilatarbelakangi Dorongan keluarga yang bersifat dan berupa pandangan, pendapat, nasehat,penghargaan, informasi dan material yang menyebabkan efek tindakan atau emosional yang menguntungkan bagi individu dalam membantu individu membuat keputusan

Pengalaman dan dorongan keluarga memberikan motivasi untuk berwirausaha bagi mahasiswa pendidikan ekonomi Universitas PGRI Ronggolawe Tuban. Berdasarkan Hasil uji F Anova dapat diketahui bahwa Pengalaman Berwirausaha dan Dorongan Keluarga secara bersama-sama berpengaruh terhadap Motivasi Berwirausaha. Hasil Uji regresi secara parsial dan Hasil uji regresi simultan menunjukan bahwa Pengalaman Berwirausaha dan dorongan keluarga memberikan pengaruh terhadap Motivasi Berwirausaha dan ada pengaruh faktor (variabel) tidak dimasukkan dalam model ini. Berdasarkan hasil wawancara Faktor (variabel) lain tersebut adalah pengaruh teman sepermainan dan lingkungan masyarakat.

\section{PENUTUP}

\section{Kesimpulan}

Berdasarkan hasil penelitian yang telah dilakukan, maka dapat disimpulkan bahwa;

1. Pengalaman berwirausaha dan dorongan keluarga memberikan pengaruh terhadap motivasi bagi mahasiswa pendidikan ekonomi Universitas PGRI Ronggolawe Tuban.

2. Pengalaman Berwirausaha dan Dorongan Keluarga secara bersama-sama berpengaruh terhadap Motivasi Berwirausaha.

3. Terdapat faktor (variabel) lain yang tidak masuk dalam model ini yang memberi pengaruh terhadap motivasi untuk berwirausaha, faktor (variabel) tersebut adalah teman sepermainan dan lingkungan masyarakat.

\section{DAFTAR PUSTAKA}

Kasmir. 2011. Kewirausahaan. Jakarta: PT.Rajagrafindo Persada

Kristanto, Heru HC. 2009. Kewirausahaan (Entrepreneurship) Pendekatan Manajemen dan Praktik. Yogyakarta: Graha Ilmu. 
Nurwakhid. 1995. Usaha Pengembangan Motivasi Murid SMK Terhadap Kewirausahaan di Kota Semarang (Laporan Penelitian). Semarang: IKIP Semarang.

Riyanti, Benedicta Prihatin Dwi. 2003. Kewirausahaan Dari Sudut Pandang Psikologi Kepribadian. Jakarta: PT. Grasindo.

Slameto. 2003. Belajar dan Faktor-Faktor yang Mempengaruhi. Jakarta: Rineka Cipta.

Sugiyono. 2010. Metode Penelitian Pendidikan Pendekatan Kuantitatif, Kualitatif, Dan $R \& D$. Bandung: Alfabeta

Suryana. 2013. Kewirausahaan Kiat dan Proses Menuju Sukses. Jakarta: SALEMBA EMPAT

Venesaar, Ene. (2006). Students Attitudes and Intentions toward Entrepreneurship at Tallinn University of Technology. TUTWPE Working Papers. (154), 97-11. 